\title{
Pathogenicity of isolates of Magnaporthe spp. from wheat and grasses infecting seedlings and mature wheat plants in Argentina
}

\author{
A. E. Perelló ${ }^{a b c *}$, I. Martinez ${ }^{a b}$, A. Sanabria ${ }^{a b c}$, R. Altamirano ${ }^{a}$ and J. V. Sibole ${ }^{d}$ \\ ${ }^{a}$ Facultad de Ciencias Agrarias y Forestales de la Universidad Nacional de La Plata, (FCAyF UNLP), Calle 60 y 119 (1900), La Plata, Buenos \\ Aires, Argentina; ${ }^{b}$ Fitopatología Centro de Investigaciones de Fitopatología (CIDEFI), La Plata, Buenos Aires, 1900, Argentina; ${ }^{\mathrm{c} C o n s e j o}$ \\ Nacional de Investigaciones Científicas y Técnicas (CONICET), 4 Curso de Cálculo Estadístico y Biometría, La Plata, Buenos Aires, \\ Argentina; and ' Departament de Biologia, Universitat de les Illes Balears, Cta. de Valldemossa km 7.5, 07122 Palma (IIles Balears), Spain
}

Wheat blast of wheat (Triticum aestivum), caused by Magnaporthe oryzae pathotype triticum (MoT; anamorph Pyricularia oryzae) is a destructive disease in the South American countries of Brazil, Paraguay and Bolivia. In Argentina, the fungus was recently recorded on wheat and barley plants in the northeast part of the country, Buenos Aires and Corrientes Provinces, with a potential for spreading. This work aimed to study, for the first time, the morphocultural and pathogenic characteristics of Magnaporthe isolates collected from wheat and other herbaceous species in Argentina and three neighbouring countries (Paraguay, Brazil and Bolivia) and determine their aggressiveness on wheat varieties. Statistical differences among isolates, culture media, and development conditions were found for conidia colour, growth rate, size and sporulation rate. Pathogenicity tests performed on seedlings with 19 isolates of Magnaporthe spp. under greenhouse conditions showed a maximum disease severity of $55.3 \%$ and $66.7 \%$ for varieties BIOINTA 3004 and Baguette 18, respectively. Weed and grass isolates were infectious on wheat, demonstrating their potential epidemiological role on the disease. Spike disease severity was $34.6 \%$ for the host $\times$ pathogen interaction of BIOINTA $3004 \times$ PY22. Observed symptoms included partial or total spike bleaching, and glume and rachis discolouration. The 1000-grain weight was significantly reduced to $38.5 \%$ and $63.1 \%$ for cultivars BIOINTA 3004 and Baguette 18, respectively. The disease affected grain germination, which fell to $65.9 \%$ for seeds infected with the PYAR22 isolate. Symptoms observed in infected grains were partial spotting, grain softening, and rot symptoms with the presence of a greyish mould.

Keywords: disease severity, Magnaporthe, pathogenicity, Pyricularia oryzae, wheat, wheat blast

\section{Introduction}

Magnaporthe oryzae pathotype triticum (MoT; also known as Magnaporthe grisea; anamorph Pyricularia oryzae) causes brusone or wheat blast, a disease of wheat that has become a serious limitation to wheat crop production, especially in the tropical areas of the Southern Cone region of South America (Kohli et al., 2011). This disease was first described in Brazil in the north of Paraná State in 1985 (Igarashi et al., 1986), and then spread to other wheat-growing areas of Brazil (Goulart \& Paiva, 2000). Magnaporthe oryzae has also caused severe disease in wheat in the neighbouring countries of Paraguay, Uruguay and Bolivia (Kohli et al., 2011). Historically, the disease has been reported on wheat from India (McRae, 1922),

*E-mail: anaperello2@yahoo.com.ar

Published online 15 February 2017
Pakistan (Malik \& Khan, 1943), USA (Rush \& Carver, 1973) and Brazil (Igarashi et al., 1986; Diekmann \& Putter, 1995). In May 2011, M. oryzae was isolated from a single severely blasted wheat head found in a wheat test plot in Kentucky. This Kentucky strain was identified as a native US ryegrass isolate and blast has not been identified since on wheat in the US (Bockus et al., 2013).

Currently, wheat blast is mainly limited to the tropical regions of South America (the lowlands and the highlands (3000 m a.s.l.); Vales et al., 2016) including Bolivia, central and south-central Brazil, and Paraguay. However, the continuous increase in greenhouse gases, leading to global warming and associated climate changes, could provide favourable conditions for the spread of the disease to other parts of the world. Any eventual transfer of the disease is likely to cause devastating effects if there are no additional research programmes for disease prevention (Kohli et al., 2011). An outbreak of wheat blast has occurred for the first time in Bangladesh; the epidemic spread to $16 \%$ of the cultivated area, with yield losses reaching up to $100 \%$ (Aman, 2016). It is feared that the disease could eventually spread into the Indo-Gangetic Plain through 
Bangladesh, northern India and eastern Pakistan (Callaway, 2016). Phylogenomic and population analyses of the wheat blast outbreak in Bangladesh revealed that it was most probably caused by a wheat-infecting South American lineage of $M$. oryzae and, thus, was most probably introduced into Asia from South America (Islam et al., 2016). In 2007, the disease was detected in Argentina during a summer wheat trial in the province of Chaco (Cabrera \& Gutiérrez, 2007; Alberione et al., 2008). In 2012, the fungus was isolated from wheat crops in experimental field trials of the Instituto Fitotécnico de Santa Catalina, Lavallol, Buenos Aires and was also found in the accompanying weeds of these wheat trials (Perelló et al., 2015). Magnaporthe oryzae was also reported in barley cv. Alicia INTA in Corrientes Province of Argentina (Gutiérrez \& Cúndom, 2015). These findings call for intensive monitoring and surveillance of the wheat blast pathogen to limit its further spread.

The most significant symptoms of wheat blast occur in the spikes, which may have total or partial bleaching, and could lead to grain infertility and/or failure of grain filling, depending on the extent of rachis infection (Urashima et al., 2004). At its worst, the disease can partially or completely damage the spike, resulting in no grain production. The fungus can also attack the leaves and stems. The shape, colour, size and number of lesions vary according to environmental conditions, plant age and degree of susceptibility of the wheat variety. Magnaporthe oryzae is characterized by simple, short, delicate, conidiophores that carry clusters of conidia at their tips. Conidia are typically obpyriform, hyaline, truncated with a short tooth at the base, 2-septate, usually with a pointed acute apex, 20-25 × 9-12 $\mu \mathrm{m}$. Magnaporthe oryzae can infect major cereals such as rice, its bestknown host, as well as wheat, barley, rye, triticale and oats. The fungus also affects a wide range of weeds that are normally found in association with cereals, such as Brachiaria, Cynodon dactylon, Cyperus rotundus, Digitaria sanguinalis, Echinochloa crus-galli, Eleusine indica, Lolium multiflorum, Pennisetum setosum and Stenotaphrum secundatum (St Augustine grass), some of which have been identified in Argentina as secondary hosts (Martinez, 1971; Wolcan \& Perelló, 1987; Gutiérrez et al., 2000). However, little is known about the importance of inoculum proceeding from secondary hosts under natural conditions (Kohli et al., 2011).

The pathogen is favoured by average temperatures of $25^{\circ} \mathrm{C}$ or higher, and humidity conditions of $80 \%$ or higher. Such conditions, if perpetuated by $24 \mathrm{~h}$ or more of rain when the host is in the flowering stage, lead to particularly effective infection and spread to the spikes. The absence of epidemiological studies of this new pathogen makes it difficult to assess areas of potential risk in Argentina. The fungus overwinters in infected wheat stubble and weed seeds, both of which can act as a source of primary inoculum for disease development (Kohli et al., 2011). Transmission of the fungus by wheat seed has been demonstrated by Goulart \& Paiva (1990), although little is known about the importance of seed infection in the epidemiology of the disease (Urashima et al., 1993). However, the presence of the pathogen in the seed is directly related to germination and vigour, as this fungus can be transmitted to the progeny causing serious losses to seed producers and farmers (Teixeira \& Machado, 2003). Infection of seed is one of the mechanisms of long distance diffusion, which results in the introduction of the disease into other states, regions and countries. When infected, seeds appear wrinkled, small, shrivelled, and with low specific weight (Consolo et al., 2016). Consequently, most of these seeds are eliminated in the process of harvesting, which explains the low incidence in commercial wheat seed. A great diversity in aggressiveness of $M$. oryzae on wheat cultivars has been reported and is under investigation (Perelló et al., 2016), although, to date, no resistant varieties of wheat blast are available (Urashima et al., 2004). Results from the germplasm tested reveal a differential response of cultivars/lines to $M$. oryzae, which can be attributed to the high variability of the strains that make up the population of the pathogen (Cruz et al., 2008).

One of the strategies to prevent losses by wheat blast is the use of healthy seeds, because contaminated seeds are a source of primary inoculum of the disease (Goulart \& Paiva, 1990). Given the threat of wheat blast to wheat crops in South America, and the alarming recent expansion of this pathogen in Asia (Bangladesh), the aims of this paper were to (i) determine the morphological and in vitro traits of this fungus; (ii) assess the virulence of MoT isolates collected from Argentinian wheat and grasses; (iii) analyse the response of wheat cultivars after inoculation with MoT isolates in both seedling and spike stages under greenhouse conditions, and (iv) examine the seedborne infection of MoT in several wheat varieties.

\section{Materials and methods}

The experiments were conducted at the laboratory and greenhouse of the Centro de Investigaciones de Fitopatología (CIDEFI), Facultad de Ciencias Agrarias y Forestales, Universidad Nacional de La Plata, Buenos Aires Province, Argentina $\left(34^{\circ} 52^{\prime} \mathrm{S}, 57^{\circ} 58^{\prime} \mathrm{W}\right)$ from March to December 2015.

\section{Collection and isolation of blast pathogen}

Samples of wheat (Triticum aestivum) spikes and leaves showing typical blast symptoms were collected from the experimental fields of the Instituto Fitotecnico Santa Catalina, Lavallol, Buenos Aires, in 2012. Weeds and grasses showing symptoms were also collected at the Estación Expermental Julio Hirschhorn, Los Hornos, Buenos Aires, Argentina (Table 1). Infected tissues were cut into small pieces and surface sterilized by dipping in $0.7 \%$ ethanol for $2 \mathrm{~min}$, then a $5 \%$ sodium hypochlorite solution for $2 \mathrm{~min}$; afterwards samples were rinsed two times with sterile distilled water, dried with sterile tissue paper and then transferred onto water agar $(6 \%)$. The mycelium resulting from the plant tissue was subcultured on oatmeal agar (OMA) and incubated at $25^{\circ} \mathrm{C}$ for 10 days. Isolates were identified by their conidial morphology, according to the criteria of Ellis (1971, 1976). The isolates were stored for long-term preservation at $-20^{\circ} \mathrm{C}$, to avoid loss of pathogenicity and the ability to 
Table 1 Isolates of Magnaporthe sp. tested for infection of wheat cultivar leaves

\begin{tabular}{|c|c|c|c|}
\hline Code & Origin & $\begin{array}{l}\text { Organ from } \\
\text { where the } \\
\text { fungus was } \\
\text { isolated }\end{array}$ & Host \\
\hline PYLO & FCAyF UNLP Exp. Sta & Leaf & Lolium multiflorum \\
\hline PYST & FCAyF UNLP Bot. Gar. & Leaf & $\begin{array}{l}\text { Stenotaphrum } \\
\text { secundatum }\end{array}$ \\
\hline PYECH & FCAyF UNLP Exp. Sta. & Leaf & $\begin{array}{l}\text { Echinochloa } \\
\text { crus-galli }\end{array}$ \\
\hline PYCY & FCAyF UNLP Exp. Sta & Leaf & Cynodon dactylon \\
\hline PYCR & FCAyF UNLP Exp. Sta & Leaf & Cyperus rotundus \\
\hline PY10 & IFSC-FCAyF UNLP & Spike rachis & Triticum aestivum \\
\hline PY12 & IFSC-FCAyF UNLP & Spike rachis & T. aestivum \\
\hline PY13 & IFSC-FCAyF UNLP & Spike rachis & T. aestivum \\
\hline PY15 & IFSC-FCAyF UNLP & Spike rachis & T. aestivum \\
\hline PY16 & IFSC-FCAyF UNLP & Spike rachis & T. aestivum \\
\hline PY18 & IFSC-FCAyF UNLP & Spike rachis & T. aestivum \\
\hline PY19 & IFSC-FCAyF UNLP & Spike rachis & T. aestivum \\
\hline PY20 & IFSC-FCAyF UNLP & Spike rachis & T. aestivum \\
\hline PY21 & IFSC-FCAyF UNLP & Spike rachis & T. aestivum \\
\hline PY22 & IFSC-FCAyF UNLP & Spike rachis & T. aestivum \\
\hline PYBOL & Bolivia, GAU-Go & Spike rachis & T. aestivum \\
\hline PYBR & Brazil, GAU-Go & Spike rachis & T. aestivum \\
\hline PYAZ & PRFP-Sta Fe & Panicle rachis & Oryza sativa \\
\hline PYPG & Paraguay & Spike rachis & T. aestivum \\
\hline
\end{tabular}

FCAyF UNLP, Facultad de Ciencias Agrarias y Forestales de la Universidad Nacional de La Plata, Buenos Aires, Argentina; Exp. Sta., Experimental Station Julio Hirschorn, FCAyF UNLP; Bot. Gar., Botanical Garden, FCAyF UNLP; IFSC, Phytotechnical Instutute Santa Catalina, FCAyF UNLP; GAU-Go, Georg August Universität, Göttingen, Germany; PRFP-Sta Fe, particular rice field producer, Santa Fe, Argentina.

sporulate, following the preservation technique of Magnoporthe conidia of Gouchang et al. (1989).

\section{Characterization of MoT isolates and mycelia growth on different culture media}

Growth characteristics of four isolates of MoT (PY22, PYPG, PYBR, PYBOL) were studied on three solid media: V8 agar (V8A), OMA and rice agar (RA). All media were inoculated with $5 \mathrm{~mm}$ mycelium discs cut from the periphery of actively growing cultures of each MoT isolate and incubated at $25 \pm 2{ }^{\circ} \mathrm{C}$ for 9 days, with alternating cycles of $12 \mathrm{~h}$ light (3500 lux) plus near-UV light $(365 \mathrm{~nm})$ followed by $12 \mathrm{~h}$ dark, or with continuous darkness. Treatments were OMA 12/12 h light/dark, OMA continuous darkness, V8A 12/12 h light/dark, V8A continuous darkness, RA $12 / 12 \mathrm{~h}$ light/dark, and RA continuous darkness. Each treatment was replicated four times. After 9 days, colonies were observed for morphological and cultural characteristics: mycelial colour (using the colour codes of Rayner, 1970), margin type, texture, sporulation, and growth rate were recorded. Colony diameters $(\mathrm{mm})$ of each isolate grown on Petri dishes were measured in two directions at 2-day intervals until the tenth day of incubation. Fifty conidial spores of these isolates were measured, length and width, by light microscopy, using ocular and stage micrometers. Degree of sporulation was measured by flooding the Petri dish with $5 \mathrm{~mL}$ sterile distilled water and dislodging the conidia with a bent glass rod. The resulting suspension was filtered through cheesecloth and the concentration of conidia was determined with a haemocytometer.

\section{Pathogenicity test under greenhouse conditions}

In order to evaluate isolate aggressiveness, two greenhouse trials were conducted. The experiments were performed with common wheat BIOINTA 3004 (BIOINTA) and Baguette 18 (Baguette), two commercial cultivated varieties in the wheat-producing area of Buenos Aires province. Ten seeds per pot were sown in black plastic pots (30 L capacity), and cultured in the greenhouse of the CIDEFI. Seedlings were thinned to six per pot. A total of 30 pots per cultivar were analysed.

For inoculum production, isolates were cultured on OMA for 10 days. Conidia were suspended in sterile distilled water and their concentration was adjusted to 50000 spores $\mathrm{mL}^{-1}$ using a haemocytometer. The same concentration was used for leaf and spike inoculation, in two separate experiments.

Aggressiveness was evaluated by inoculating leaves of wheat seedlings of the two cultivars with 15 isolates of MoT (Table 1). Leaves were inoculated at the three-emerged-leaf stage (growth stage Z1.3; Zadoks, 1972) by spraying the conidial suspension onto the leaves until run-off. A volume of $20 \mathrm{~mL}$ of the adjusted spore suspension from a given isolate was sprayed on each individual pot. After inoculation, plants were covered individually with polythene plastic sheets for incubation and kept at $100 \%$ relative humidity for $48 \mathrm{~h}$. Controls were sprayed with $20 \mathrm{~mL}$ distilled water only. Two pots with six plants per isolate, per cultivar, were tested. Infection was assessed at 7 days after inoculation; symptoms were recorded and severity (\%) was calculated as [diseased leaf area/total leaf area] $\times 100$.

Wheat spike infection patterns were evaluated by the inoculation of grown wheat plants of both cultivars with five isolates of Magnaporthe sp.: PYLO, PYCY, PY13, PY18 and PY22. These isolates were selected from the results given by the leaf experiment. Spikes were inoculated at anthesis (growth stage 65; Zadoks, 1972). The spikelets of each spike were sprayed with the conidial suspension until run-off. A volume of $2 \mathrm{~mL}$ of the adjusted spore suspension from a given isolate was sprayed on each spike. Control spikelets were sprayed with $2 \mathrm{~mL}$ of distilled water only. After inoculation, spikes were covered individually with black plastic bags to maintain $100 \%$ relative humidity for $24 \mathrm{~h}$ and then the bags were replaced with clear plastic bags for another $24 \mathrm{~h}$. Plants were evaluated at 7, 15 and 21 days post-inoculation.

Disease severity was calculated as the percentage of diseased spikelets over the total number of spikelets on each spike.

The area under the disease progress curve (AUDPC) was calculated from the disease ratings recorded previously, according to the formula of Shaner \& Finney (1977):

$$
\text { AUDPC }=\sum_{i=1}^{n-1}\left(\frac{X_{i}+X_{i+1}}{2}\right)\left(t_{i+1}-t_{i}\right)
$$

where $X_{i}=$ disease severity at the $i$ th observation, $t_{i}=$ days at the $i$ th observation, and $n=$ total number of observations.

At maturity, heads of the inoculated spikes and controls were harvested and hand threshed to avoid loss of infected kernels that were light and shrivelled. The 1000-grain weight for each treatment was calculated.

Data were statistically analysed using the nonparametric Kruskal-Wallis test and the software infostat and STATISTICA.

\section{Effects of Magnaporthe sp. on wheat seed germination and quality}

Seedborne infection of wheat by MoT and its transmission to seedlings were studied quantitatively by the standard blotter 
method, using artificially infected seeds of three commercial wheat cultivars, BIOINTA 3004, Baguette 18 and Klein Proteo. Seeds were disinfected with $5 \%$ sodium hypochlorite for $5 \mathrm{~min}$ and rinsed three times with sterile distilled water before being inoculated with five isolates of MoT: PY22, PYBOL, PYBR, PYPG and PYAZ. For inoculation, the seeds were placed in a suspension of $1.5 \times 10^{5}$ conidia $\mathrm{mL}^{-1}$ and a volume 2.5 times its spore mass for $1 \mathrm{~h}$. Controls were placed in distilled water only for the same period.

Four hundred seeds were arranged in replicates of 50 seeds per plastic tray lined with three layers of water-soaked blotter paper, with eight trays used per isolate. Seeds were deposited with sterile forceps in each tray and were incubated at $20 \pm 2{ }^{\circ} \mathrm{C}$ for 7 days in cycles of $12 \mathrm{~h}$ near-UV light $/ 12 \mathrm{~h}$ darkness. Seeds were observed after 7 days to determine whether they were infected by MoT. Percentage of germinated seeds, percentage infection, the symptoms of emerged seedlings and, if infected, the location of the fungus were recorded after observation through a stereomicroscope.

\section{Data analysis}

The statistical analysis was conducted using a one-way ANOVA test. Mean comparisons of treatments were performed by Tukey's test $(\alpha=0.05)$.

\section{Results}

\section{Characterization of Magnaporthe sp. isolates and mycelial growth on different culture media}

The isolates showed different growth characteristics on each of the three mycological media and these are

Table 2 Colony description of four isolates of Magnaporthe oryzae pathotype triticum under incubation conditions of (a) $12 \mathrm{~h}$ light/12 h dark and (b) $24 \mathrm{~h}$ continuous darkness at $25^{\circ} \mathrm{C}$, plated on oatmeal agar (OMA), V8 agar (V8A) or rice agar (RA)

\begin{tabular}{|c|c|c|c|c|c|c|c|c|}
\hline Light regime & $\begin{array}{l}\text { Culture } \\
\text { medium }\end{array}$ & Isolate & $\begin{array}{l}\text { Colony } \\
\text { shape }\end{array}$ & Colony surface & Elevation & Colour $^{a}$ & Edge & Internal structure \\
\hline \multirow{11}{*}{$\begin{array}{l}\text { (a) } 12 \mathrm{~h} \\
\text { light/12 h } \\
\text { dark }\end{array}$} & \multirow[t]{4}{*}{ OMA } & PY22 & Round & $\begin{array}{l}\text { Concentric rings, } \\
\text { rough }\end{array}$ & Diffuse & $\begin{array}{l}120 \text { Pale olivaceous } \\
\text { grey }\end{array}$ & Eroded & Cottony-filamentous \\
\hline & & PYPG & Round & Rough, radiated & Diffuse & $\begin{array}{l}120 \text { Pale olivaceous } \\
\text { grey }\end{array}$ & Eroded & Cottony-filamentous \\
\hline & & PYBR & Round & $\begin{array}{l}\text { Concentric rings, } \\
\text { rough }\end{array}$ & Diffuse & $\begin{array}{l}120 \text { Pale olivaceous } \\
\text { grey }\end{array}$ & Eroded & Cottony-filamentous \\
\hline & & PYBOL & Round & $\begin{array}{l}\text { Concentric rings, } \\
\text { rough }\end{array}$ & Diffuse & $\begin{array}{l}120 \text { Pale olivaceous } \\
\text { grey }\end{array}$ & Eroded & Cottony-filamentous \\
\hline & \multirow[t]{4}{*}{ V8A } & PY22 & Round & Smooth flat & Middle high & 121 Olivaceous grey & Whole border & Granular-filamentous \\
\hline & & PYPG & Round & Concentric rings & Middle high & 48 Olivaceous & Whole border & Granular-filamentous \\
\hline & & PYBR & Round & $\begin{array}{l}\text { Concentric rings, } \\
\text { rough }\end{array}$ & Middle high & $\begin{array}{l}69 \text { Dark herbage } \\
\text { green }\end{array}$ & Whole border & Granular-filamentous \\
\hline & & PYBOL & Round & Concentric rings & Middle high & 48 Olivaceous & Whole border & Granular-filamentous \\
\hline & \multirow{3}{*}{ RA } & PYPG & Round & Rough, radiated & Flat & 117 Pale mouse grey & Whole border & Velvety \\
\hline & & PYBR & Round & $\begin{array}{l}\text { Concentric rings, } \\
\text { rough }\end{array}$ & Flat & $\begin{array}{l}120 \text { Pale olivaceous } \\
\text { grey }\end{array}$ & Eroded & Velvety \\
\hline & & PYBOL & Round & Concentric rings & Flat & 121 Olivaceous grey & Eroded & Velvety \\
\hline \multirow{12}{*}{$\begin{array}{l}\text { (b) } 24 \mathrm{~h} \\
\text { dark }\end{array}$} & \multirow[t]{4}{*}{ OMA } & PY22 & Circular & Rough & Diffuse & White & Eroded & Cottony-filamentous \\
\hline & & PYPG & Circular & Rough & Diffuse & White & Eroded & Cottony-filamentous \\
\hline & & PYBR & Circular & Smooth flat & Flat & 91 Greenish glaucous & Eroded & Cottony-filamentous \\
\hline & & PYBOL & Circular & Smooth flat & Flat & 122 Iron grey & Eroded & Granular smooth \\
\hline & \multirow[t]{4}{*}{ V8A } & PY22 & Circular & Smooth flat & Flat & 122 Iron grey & Whole border & Cottony-filamentous \\
\hline & & PYPG & Circular & Smooth flat & Flat & 121 Olivaceous grey & Whole border & Granular smooth \\
\hline & & PYBR & Circular & Smooth flat & Flat & $\begin{array}{l}120 \text { Pale olivaceous } \\
\text { grey }\end{array}$ & Whole border & Cottony \\
\hline & & PYBOL & Circular & Smooth flat & Flat & 133 Pale greenish grey & Whole border & Granular smooth \\
\hline & \multirow[t]{4}{*}{ RA } & PY22 & Circular & Rough & $\begin{array}{l}\text { High level in the } \\
\text { periphery and } \\
\text { flat in the centre }\end{array}$ & 91 Greenish glaucous & Whole border & Velvety-filamentous \\
\hline & & PYPG & Circular & Rough & $\begin{array}{l}\text { High level in the } \\
\text { periphery and } \\
\text { flat in the centre }\end{array}$ & 91 Greenish glaucous & Whole border & Velvety-filamentous \\
\hline & & PYBR & Circular & Rough & $\begin{array}{l}\text { High level in the } \\
\text { periphery and } \\
\text { flat in the centre }\end{array}$ & 91 Greenish glaucous & Eroded & Velvety-filamentous \\
\hline & & PYBOL & Circular & Rough & $\begin{array}{l}\text { High level in the } \\
\text { periphery and } \\
\text { flat in the centre }\end{array}$ & 91 Greenish glaucous & Eroded & Velvety-filamentous \\
\hline
\end{tabular}

${ }^{a}$ Colour codes are described in Rayner (1970). 
summarized in Table 2. Under growth conditions of $12 \mathrm{~h}$ light/12 h dark, colonies were round in shape for all isolates and culture media, while the colony surface on OMA had variations: concentric rings with rough surfaces for isolates PY22, PYBR and PYBOL, or a rough, radiated surface for the PYPG isolate. On V8A, the PY22 isolate showed a smooth, flat surface, while the other isolates formed concentric rings. On RA, PYPG and PY22 isolates presented a rough surface while the rest of tested isolates formed concentric rings. Colony elevation was diffuse for all isolates tested on OMA, middle to high when cultured on V8A and flat on RA. Colony edges were mostly full-margin with some exceptions in which some sectors presented an eroded edge. The internal structure had filamentous, cottony mycelium in all isolates grown on OMA, granular-filamentous when grown on V8A, and velvety on RA. The colour also varied under these growth conditions: all OMAgrown colonies showed a pale olivaceous grey colour (120), PYBOL and PY22 showed an olivaceous grey colour (121) for V8A, while PYPG-grown colonies had an olivaceous colour (48). On RA, PYPG and PY22 colonies were a pale mouse grey colour (117), PYBR was pale olivaceous grey (120) while PYBOL had an olivaceous grey (121) colour (Table 2a).

When grown in continuous darkness, all isolates for the three culture media tested grew circular colonies. The colony surface of PYPG and PY22 grown on OMA was rough, although PYBOL and PYBR colonies were smooth. All isolates tested produced smooth-surfaced colonies on V8A, yet a rough surface was produced on RA. PYPG and PY22 had diffusely elevated colonies on OMA, although flat colonies were observed for the rest of the isolates tested. On V8A all isolates had flat-topped colonies, while on RA colonies had a combination of high elevation along the edge but were flat in the centre. An eroded edge was found for all isolates on OMA, intact border on V8A, and of both types on RA, according to the isolate. Colony internal structure differed according to the isolate/medium combination: cottonyfilamentous, granular, cottony-stringy, or a granular smooth structure. Colony colours on OMA were: white, greenish (91), or iron grey (122), while on V8 colours ranged from iron grey (122), olivaceous grey (121), grey olivaceous (120) to pale greenish grey (133). Interestingly, all isolates on RA showed a greenish glaucous (91) colour (Table 2b).

Under growth conditions of $12 \mathrm{~h}$ light/12 h dark, the culture medium OMA produced the highest growth rates for all the isolates. In this medium, the PYPG growth rate $\left(0.79 \mathrm{~cm} \mathrm{day}^{-1}\right)$ was statistically higher than the other isolates (Table 3a; Fig. 1a). When grown in continuous darkness, the ANOVA for growth rates indicated no significant differences between isolate $\times$ culture medium interaction, but there were differences in overall averages among culture media (Table $3 \mathrm{~b}$ ). OMA and RA were the media in which isolates had the highest rate of growth (Fig. 1b).
Table 3 Analysis of variance (ANOVA) of the growth rate (cm/day) for isolates of Magnaporthe oryzae pathotype triticum growing under (a) $12 \mathrm{~h}$ light/12 h dark and (b) $24 \mathrm{~h}$ continuous darkness

\begin{tabular}{lll}
\hline & \multicolumn{2}{l}{ Variation (\%) } \\
\cline { 2 - 3 } Source of variation & (a) $12 \mathrm{~h}$ & (b) $24 \mathrm{~h}$ \\
light/12 h dark & dark \\
\hline Isolate & $21.13^{\star *}$ & 0.54 \\
Medium & $47.07^{\star *}$ & $8.80^{\star *}$ \\
Isolate $\times$ Medium & $7.84^{\star *}$ & 0.88 \\
\hline
\end{tabular}

${ }^{*}$ Significant, $P \leq 0.05$.

Investigation of sporulation showed that, when grown in $12 \mathrm{~h}$ light/12 h dark, isolate PY22 on OMA produced the highest number of conidia compared to the rest $\left(500000\right.$ conidia $\left.\mathrm{mL}^{-1}\right)$; in contrast, PYBOL on OMA produced the lowest number of conidia (8400 conidia $\mathrm{mL}^{-1}$; Table $4 \mathrm{a}$ ). Under these growth conditions, all isolates sporulated on all media. When isolates were grown in continuous darkness, on OMA, isolate PY22 produced the highest number of conidia (15 000 conidia $\mathrm{mL}^{-1}$ ), whereas isolates PYPG and PYBR did not sporulate (Table 4b). In contrast, on V8A, all isolates sporulated highly, particularly PY22, which produced the highest number of conidia $(940000$ conidia $\mathrm{mL}^{-1}$ ) for this medium. However, the highest sporulation values compared to the other media and growth conditions were produced on RA in continuous darkness by PYBR, with 1970000 conidia $\mathrm{mL}^{-1}$, and PY22, with 1170000 conidia $\mathrm{mL}^{-1}$, although neither PYPG nor PYBOL sporulated on this medium in these conditions. Thus, not all isolates sporulated in darkness, but, within those that did sporulate, PY22 was the only isolate that sporulated in all media with high numbers of conidia (Table 4b).

Conidial shape was typically pyriform with a rounded base, narrowed apex, 2-septate, 3-celled, with the middle cells broader than the others. Under growth conditions of $12 \mathrm{~h}$ light/12 h dark, distinct differences in spore size were seen among isolates, with variability in length and width of conidia, according to the culture media tested. On V8A, larger conidia were found $(30.72 \mu \mathrm{m}$ long $\times 1.68 \mu \mathrm{m}$ wide; Table $4 \mathrm{a})$. However, under conditions of continuous darkness, no great variability in length and width of conidia was observed among isolates (Table 4b).

\section{Pathogenicity test under greenhouse conditions}

The ANOVA of the severity data indicated significant differences in disease severity $(P<0.05)$ between treatments, isolates, and cultivars after inoculation of wheat leaves with MoT. The aggressiveness of the fungus towards cultivar Baguette 18 was considerable, giving the highest disease severity values. The percentage of infection for BIOINTA ranged from $1.5 \%$ to $55.3 \%$ of the leaf area (Fig. 2a). In cultivar Baguette, severity 


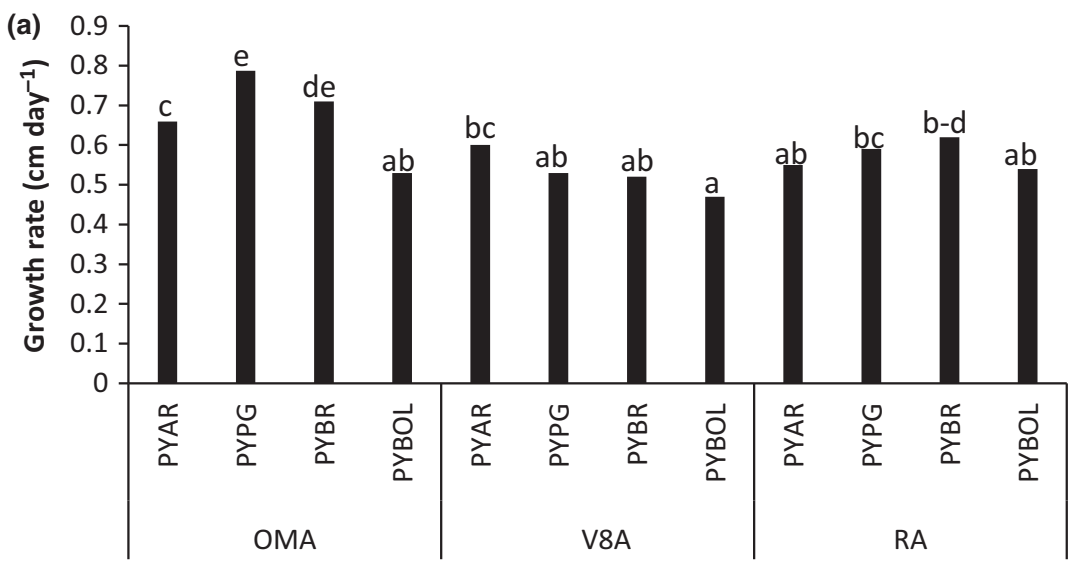

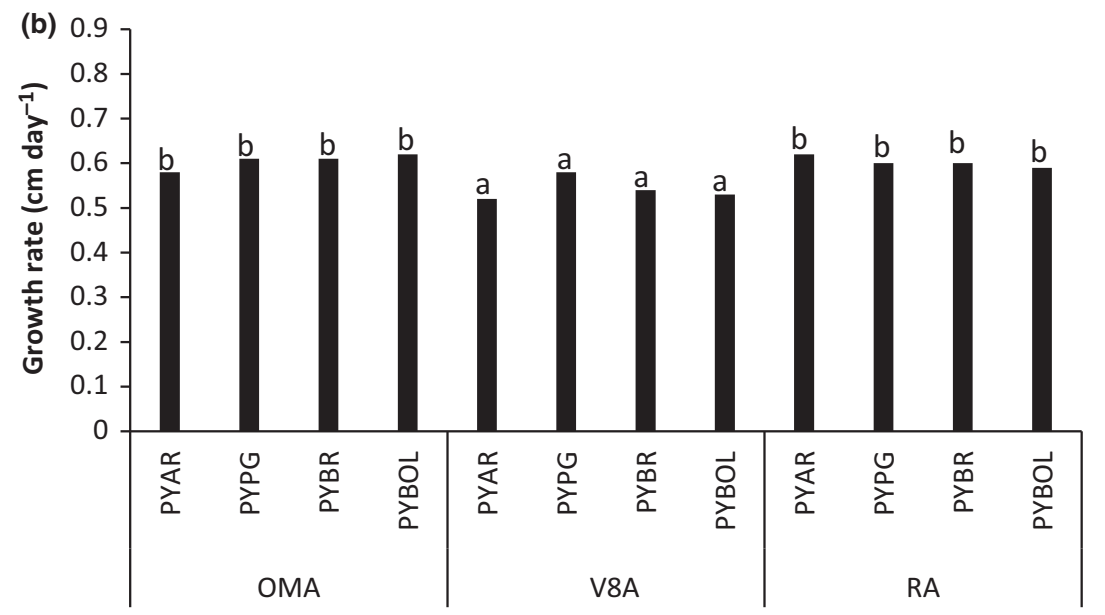

Figure 1 Growth rate $\left(\mathrm{cm} \mathrm{day}{ }^{-1}\right)$ of four isolates of Magnaporthe oryzae pathotype triticum on three culture media (oatmeal agar (OMA), V8 agar (V8A) and rice agar (RA)) under (a) $12 \mathrm{~h}$ light/12 $\mathrm{h}$ dark conditions and (b) continuous darkness. Different lower case letters above bars indicate a significant difference $(P<0.05)$. values ranged from $2.8 \%$ to $66.7 \%$ (Fig. $2 \mathrm{~b}$ ). On both cultivars, isolate PY22 caused the highest disease severity values in the ranking issued by the Kruskal-Wallis test, with $50 \%$ or more infected leaves on both cultivars tested, making it the most aggressive of all isolates tested. BIOINTA was severely infected by PY22, with a leaf infection percentage of more than $50 \%(55.3 \%)$, while Baguette 18 reached $66.7 \%$ (Fig. 2a,b).

Isolates of $M$. oryzae spp. from weeds and grasses such as Lolium sp., S. secundatum, Echinochloa sp., Bromus unioloides and Cyperus sp. were pathogenic on wheat. Symptoms commonly observed on wheat were necrotic lesions with a greyish centre and brown margin. Other types of symptoms observed were chlorotic lesions, necrotic diamond-shaped lesions, greenish necrotic lesions and elongated brown lesions, depending on the strains and cultivars analysed.

At 7 days after inoculation (dai), statistical differences in severity of disease on spikes amongst the cultivars BIOINTA and Baguette were found. Among isolates, PY22 induced the highest values of infection in cultivar BIOINTA (Fig. 3a). At 15 dai, progress of the disease was observed, with values ranging from $0 \%$ to $26.1 \%$ and $9.0 \%$ to $27.3 \%$ for BIOINTA and Baguette cultivars, respectively (Fig. 3b). At this time, isolates differed significantly for cv. BIOINTA, particularly PY22 and
PY13, and PY18 for cv. Baguette (Fig. 3b). At 21 dai, the infection values ranged between $2.4 \%$ and $34.6 \%$ for cultivar BIOINTA, and between $13.6 \%$ and $28.1 \%$ for cultivar Baguette (Fig. 3c). At this timepoint, further progress of the disease was marked, as there were significant differences between cultivars and between isolates, particularly the combination BIOINTA/PY22, which differed significantly from the rest. Overall, fungal isolates from weeds and grasses induced a lower disease severity than those from wheat.

Figures 2 and 3 show that there is specific cultivar $x$ isolate interaction for disease severity of wheat in these experiments. The cultivar BIOINTA was the most susceptible to the isolates from wheat, but was also most resistant to isolates from other species, suggesting the existence of two types of resistance mechanism.

As was observed in the wheat leaf assay, fungal isolates from weeds and grasses induced a lower severity of disease in the spikes of both cultivars. The correlation between AUDPC and severity of the disease in the spikes, assessed 21 dai, was found to be significant and higher for BIOINTA (Fig. 4a) than for Baguette (Fig. 4b). The symptoms observed were ellipsoidal necrotic lesions with a brown edge and lighter centre on the glumes, a greying rachis, and total or partial spike blanching. 
Table 4 Colony diameter, sporulation and conidia measurements of four isolates of Magnaporthe oryzae pathotype triticum growing under (a) $12 \mathrm{~h}$ light/12 $\mathrm{h}$ dark and (b) $24 \mathrm{~h}$ continuous darkness

\begin{tabular}{|c|c|c|c|c|c|c|c|}
\hline \multirow[b]{2}{*}{ Light regime } & \multirow{2}{*}{$\begin{array}{l}\text { Culture } \\
\text { medium }^{a}\end{array}$} & \multirow[b]{2}{*}{ Isolate } & \multirow{2}{*}{$\begin{array}{l}\text { Colony } \\
\text { diameter (cm) }\end{array}$} & \multirow{2}{*}{ 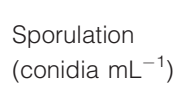 } & \multicolumn{3}{|l|}{ Conidia } \\
\hline & & & & & Length $(\mu \mathrm{m})^{\mathrm{b}}$ & Width $(\mu \mathrm{m})^{\mathrm{b}}$ & $L: W$ \\
\hline \multirow[t]{12}{*}{ (a) $12 \mathrm{~h}$ light/12 h dark } & \multirow[t]{4}{*}{ OMA } & PY22 & 8.5 & $500000^{\star *}$ & 24.9 (19.72) 16.8 & 12.0 (10.50) 9.6 & 1.8 \\
\hline & & PYPG & 8.2 & 9600 & $38.4(23.36) 16.8$ & 12.0 (10.72) 9.6 & 2.0 \\
\hline & & PYBR & 8.5 & $10400^{*}$ & $26.4(22.08) 16.8$ & 12.0 (9.92) 9.6 & 2.2 \\
\hline & & PYBOL & 8.5 & $8400^{*}$ & $36.0(21.76) 16.8$ & 19.2 (10.72) 9.6 & 2.0 \\
\hline & \multirow[t]{4}{*}{ V8A } & PY22 & 8.5 & $290000^{\star \star}$ & $36.0(30.72) 19.2$ & 14.4 (11.68) 9.6 & 2.6 \\
\hline & & PYPG & 7.8 & $310000^{* *}$ & $36.0(27.26) 21.6$ & $12.0(11.80) 7.2$ & 2.3 \\
\hline & & PYBR & 8.5 & $300000^{\star *}$ & $33.6(23.76) 16.8$ & $12.0(10.20) 7.2$ & 2.3 \\
\hline & & PYBOL & 7.8 & $200000^{\star *}$ & 48.0 (27.84) 24.0 & 16.8 (11.68) 9.6 & 2.4 \\
\hline & \multirow[t]{4}{*}{ RA } & PY22 & 8.0 & $320000^{* *}$ & 19.2 (16.32) 12.0 & 9.6 & 1.7 \\
\hline & & PYPG & 7.8 & $180000^{\star \star}$ & $26.4(25.12) 21.6$ & $9.6(7.84) 7.2$ & 3.2 \\
\hline & & PYBR & 8.4 & $300000^{* *}$ & 24.0 (19.92) 14.4 & 7.2 & 2.8 \\
\hline & & PYBOL & 8.0 & $12000^{* *}$ & $26.4(21.60) 19.2$ & $12.0(5.56) 7.2$ & 3.9 \\
\hline & \multirow{3}{*}{ OMA } & PYPG & 8.1 & $0^{*}$ & - & - & - \\
\hline & & PYBR & 8.5 & $0^{*}$ & - & - & - \\
\hline & & PYBOL & 8.5 & $10400^{*}$ & $19.4(16.32) 14.4$ & 7.36 & 2.2 \\
\hline & \multirow[t]{4}{*}{ V8A } & PY22 & 7.5 & $940000^{\star \star \star}$ & 24.0 (19.44) 16.8 & 9.6 & 2.0 \\
\hline & & PYPG & 7.4 & $200000^{\star \star}$ & $19.2(16.56) 14.4$ & 7.2 & 2.3 \\
\hline & & PYBR & 7.3 & $410000^{\star *}$ & $24.0(21.20) 19.2$ & 12.0 & 1.8 \\
\hline & & PYBOL & 7.3 & $150000^{\star *}$ & 24.0 (21.50) 19.2 & 12.0 & 1.8 \\
\hline & \multirow[t]{4}{*}{ RA } & PY22 & 7.8 & $1170000^{\star \star \star}$ & $24.0(20.46) 16.8$ & $7.2(6.94) 4.8$ & 2.9 \\
\hline & & PYPG & 7.2 & $0^{*}$ & - & - & - \\
\hline & & PYBR & 8.1 & $1970000^{* \star *}$ & 21.6 (19.12) 16.8 & 16.8 (8.72) 7.2 & 2.2 \\
\hline & & PYBOL & 8.0 & $0^{*}$ & - & - & - \\
\hline
\end{tabular}

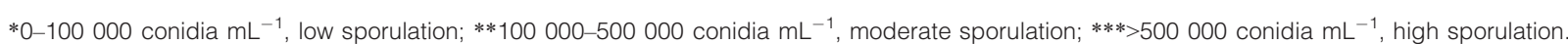

aOMA, oatmeal agar; V8A, V8 agar; RA, rice agar.

${ }^{\mathrm{b}}$ Measurements given as maximum (mean) minimum values, respectively.

Grains were visually smaller and shrivelled compared to the uninoculated controls. MoT infection significantly affected the weight of wheat grains $(P<0.05)$, with reductions of $38.5 \%$ in Baguette and $63.0 \%$ in BIOINTA when compared to the healthy controls (Fig. 5).

\section{Effect of Magnaporthe sp. on germination and quality of wheat seeds}

As shown in Figure 6, inoculation of grain with isolates of Magnaporthe spp. had a differential effect on the cultivars BIOINTA and Baguette. In Klein Proteo, germination was not altered as a result of infection by any of the five isolates tested. In Baguette, only inoculation by PYBR produced a significant reduction in germination $(15 \%)$; however, in BIONTA, the five isolates significantly affected germination with reductions of $50 \%$ or less. Symptoms observed in the three cultivars included full or partial rotting of grains with development of mycelium on the grain surface, and necrotic symptoms (spotting) at the end of the grain or along the surface. When calculating the incidence of symptoms per cultivar (Table 5), BIOINTA was shown to have the highest incidence of infected grains, which differed significantly from Klein Proteo, where four of the five isolates tested did not cause rot. Moreover, BIOINTA seedlings that developed from infected seeds presented symptoms 15 days after inoculation with PY22. It should be noted that a negative correlation between sprouted grains and grains with symptoms, particularly rot, was observed in BIOINTA, which was comparatively the most affected of the three cultivars tested in both parameters.

\section{Discussion}

Thirteen MoT isolates, one isolate of M. oryzae from rice, and five isolates of Magnaporthe spp. from weeds were studied to define and characterize its diversity and pathogenicity. The morphocultural characteristics of colonies of MoT varied, depending on the culture medium and conditions where the isolates developed. Trevathan (1982), who evaluated the growth of 20 isolates of $M$. oryzae in different culture media, determined that OMA was the most favourable medium for growth, giving a higher growth rate in 12 of the 20 isolates tested. Similarly, Gashaw et al. (2014) found OMA to be the best medium for the growth of $P$. grisea (M. oryzae) isolates causing blast disease on finger millet in Ethiopia. These results are in agreement with the present study, where better and faster fungal growth was achieved on OMA than V8A or RA. The increased performance on 


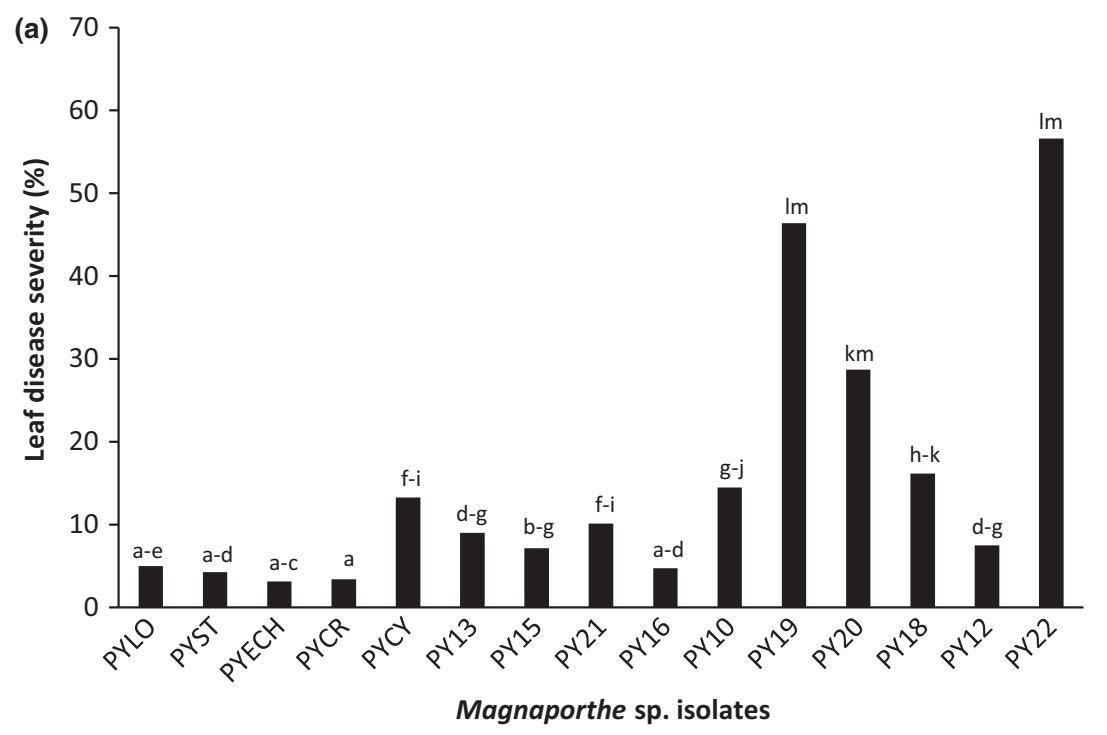

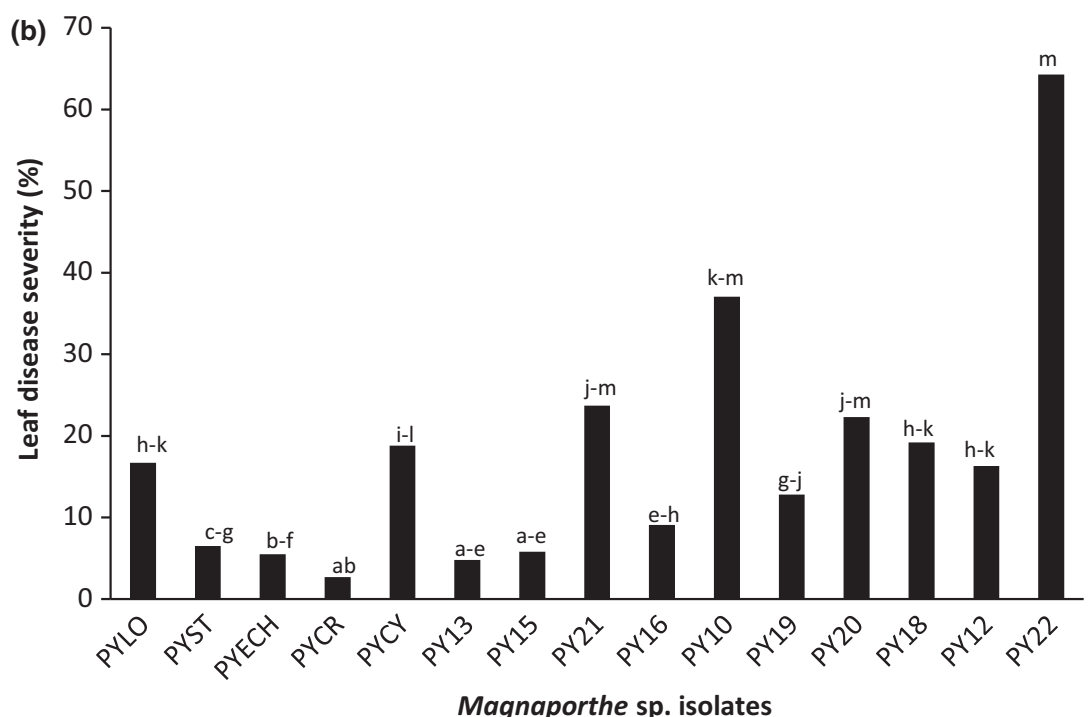

Figure 2 Disease severity (\%) on wheat leaves of (a) cv. BIOINTA 3004 and (b) cv. Baguette 18, inoculated with 10 Magnaporthe oryzae pathotype triticum (MoT) isolates (PY10, PY12, PY13, PY15, PY16, PY18-22) and five Magnaporthe sp. isolates from weeds. Different lower case letters above bars indicate a significant difference $(P<0.05)$.
OMA may be due to the higher content in this medium of microelements that are essential for good growth of Magnoporthe species, as indicated by Meena (2005). Interestingly, Meena (2005) found that differences in colony colour arise from the difference in spore production of $P$. grisea on different media. Thus, the colour differences observed in the present study might have been due to the stages of the spores on different patterns of growth.

The variability in conidial size among isolates of $M$. oryzae has been well documented by Tochinai \& Nakano (1940). Gashaw et al. (2014) concluded that it is probable that the different environmental conditions under which isolates grow exert an important influence upon the form and size of conidia of M. oryzae. This was supported by the present study, where sporulation rate differences were evident not only according to the culture medium, but also according to the growth conditions. MoT conidia developed better under 12/12 h light/dark than continuous darkness, similar to the results of Cruz et al. (2007), who showed the best results for growth and sporulation under this photoperiod. PY22, in particular, sporulated in all culture media tested and in both growth conditions, although with higher values on OMA.

Such knowledge of the appropriate culture media and culture conditions for this fungus contribute to its correct handling for increased inoculum production. This is important for use of inoculum in field experiments for screening of germplasm used for breeding and testing blast resistant varieties.

Pathogen diversity plays a major role in disease dynamics and, consequently, in the success of disease management strategies, including the development of cultivars resistant to the disease. Cruz et al. (2010), studied 18 isolates of $M$. oryzae on 70 wheat genotypes and 

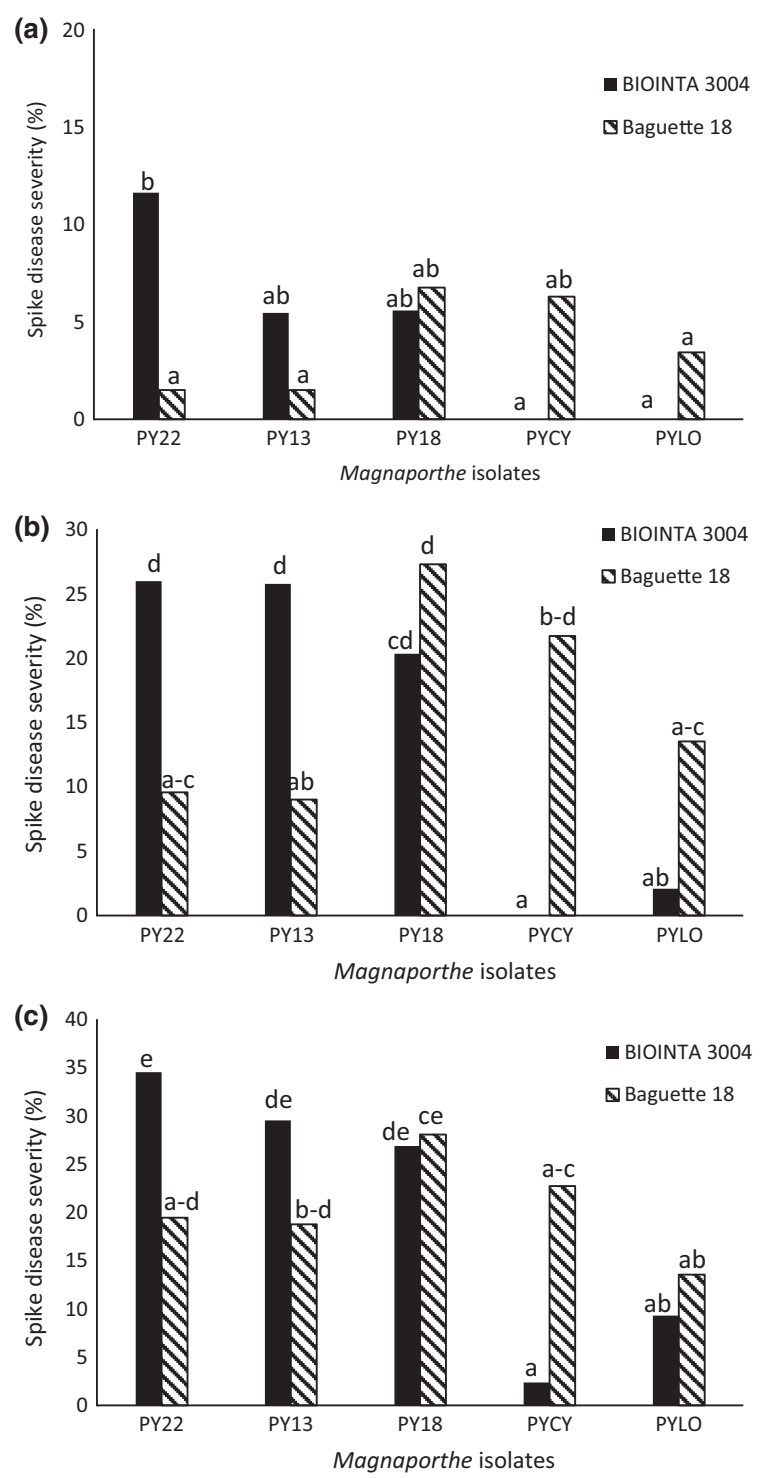

Figure 3 Disease severity (\%) on wheat spikes of cvs. BIOINTA 3004 and Baguette 18 inoculated with isolates of Magnaporthe spp. sampled (a) 7 days after inoculation (dai), (b) 14 dai and (c) 21 dai. Isolates PY22, PY18 and PY13 are from wheat and isolates PYCY and PYLO are from weeds. Different lower case letters above bars indicate a significant difference $(P<0.05)$.

concluded that variation in the degree of susceptibility by genotypes, which ranged from $9.2 \%$ to $61.6 \%$ of the leaf area affected, was indicative of the difference in partial resistance of the genotypes studied. In the present investigation, the values of leaf area affected ranged from $2.8 \%$ to $66.7 \%$, indicating the great susceptibility of the two Argentinian cultivars of wheat studied at the seedling stage to this new disease. Cruz et al. (2015) elucidated the importance of basal leaves in disease aetiology of MoT. As also observed in the present investigation, the fungus has the potential to produce conidia on wheat basal leaves and conidia production on leaves coincides with spike emergence. Additional studies are needed in Argentina to understand the significance of autoinfection in the wheat blast pathosystem; blast can progress from older to younger leaves as the season progresses and basal wheat leaves are a potential source of wheat blast inoculum. Analysing the correlation between seedling and head infection, only PY22, which showed the highest severity on leaves, also showed the highest head infection values, particularly when infecting BIOINTA. This result demonstrates that there is a level of genetic diversity among the isolates of Magnaporthe spp. tested. As at the seedling stage, the pathogenicity test at the heading stage revealed that the five isolates tested expressed different levels of aggressiveness. The partial resistance of Baguette was effective against PY22 and PY13 but not PY18; in contrast, the partial resistance of BIOINTA was effective against PY13 and PY18 but not PY22. Thus, the specificity of the partial resistance of these two cultivars seems different, at least under the experimental conditions used. BIOINTA showed good resistance to PYCY and PYLO at the three evaluation dates compared to Baguette. However, the correlation between AUDPC and disease severity on spikes was higher for BIOINTA $\left(R^{2}=\right.$ 0.98) than the correlation found for Baguette $\left(R^{2}=0.56\right)$. These results suggest that some wheat cultivars may be partially resistant to isolates of Magnaporthe spp. but less so to MoT. Similar results, showing that some wheat cultivars in the USA may be partially resistant to $M$. oryzae pathotype lolium (MoL) but less so to MoT, were recently found by Mills et al. (2015). Further studies to assess the vulnerability of wheat commercial cultivars under field conditions in Argentina should receive top priority in order to avoid potential losses associated with the impact of this new disease that will be favoured in the coming years by the warmer temperatures of climate change.

Gutiérrez et al. (2000) found and identified 11 plant species infected by the fungus $M$. oryzae namely Brachiaria extensa, Bromus catharticus, D. sanguinalis, Echinochloa colona, Leersia hexandra, Luziola peruviana, Panicum dichotomiflorum, Paspalum acuminatum, Pennisetum purpureum, Setaria glauca and S. secundatum collected from the provinces of Corrientes, Chaco and Formosa in the northeastern part of Argentina. These hosts all presented similar symptoms of blight or grey leaf spot on leaves, with elongated, elliptical spots, about $0.5-3 \mathrm{~mm}$ long, with a grey-green centre and a darker edge, surrounded by a yellowish halo. Similarly, Chavez \& Kholi (2015) confirmed the presence of $M$. oryzae in alternative species of grass weeds in Paraguay, such as B. catharticus, Brachiaria sp., Chloris gayana, Cyperus diffusus, Digitaria horizontalis and L. multiflorum. Pathogenicity tests performed with isolates from Bromus, D. horizontalis and L. multiflorum inoculated on wheat plants confirmed the potential role of these species as alternative hosts of M. oryzae (Chavez \& Kholi, 2015). Interestingly, isolates of Magnaporthe from several poaceous hosts were reported in Brazil. According to the report of Ceresini et al. (2016), Urochloa sp., 

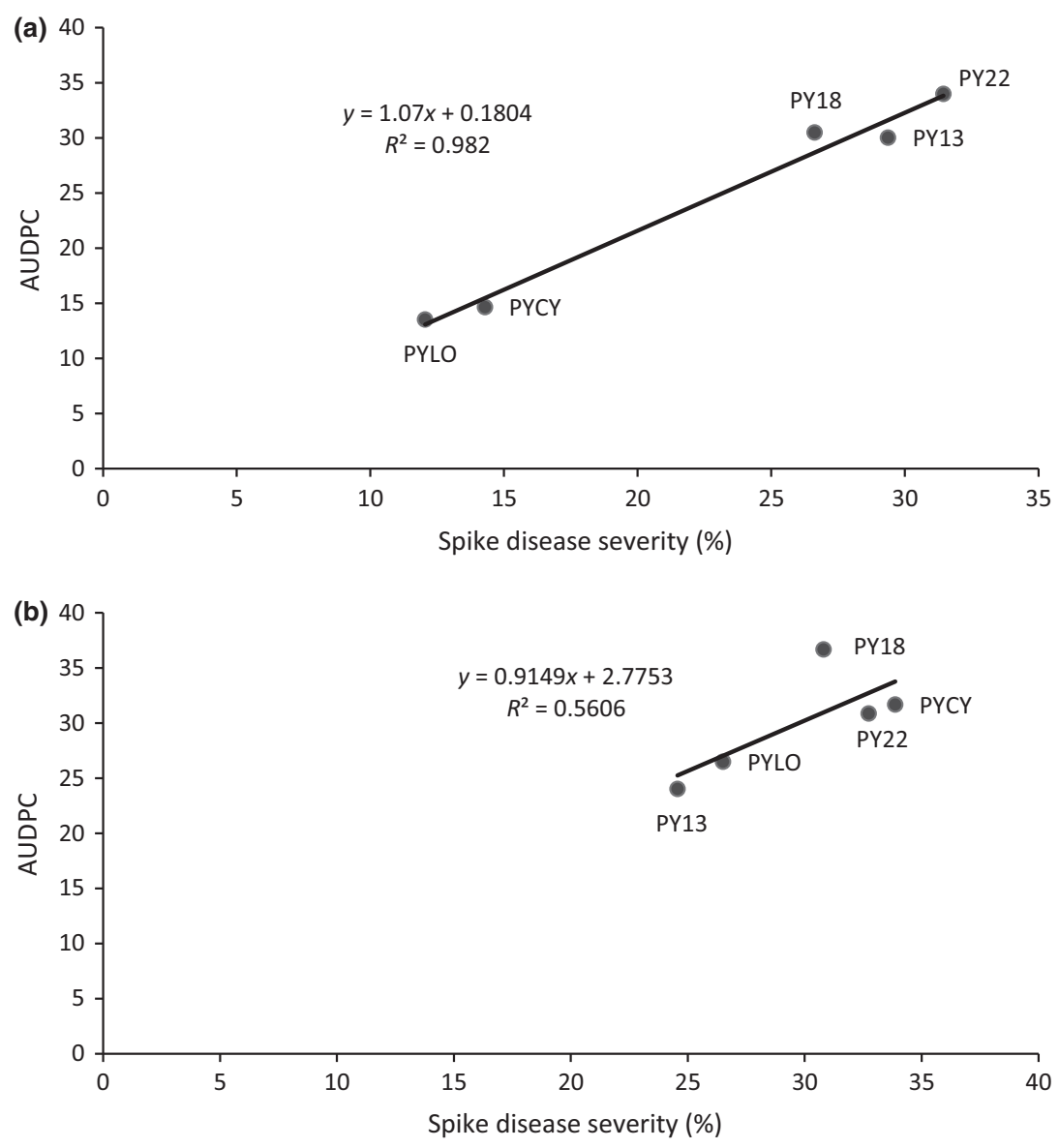

Figure 4 Correlation between area under the disease progress curve (AUDPC) and spike disease severity (\%) 21 days after inoculation of wheat cultivars (a) BIOINTA 3004 and (b) Baguette 18 with Magnaporthe spp.

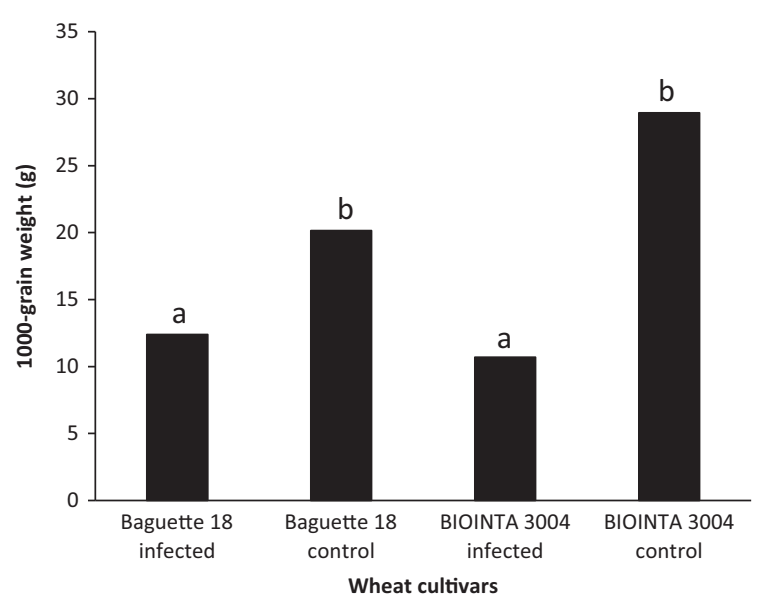

Figure 5 Effect of infection by Magnaporthe sp. on 1000-grain weight of wheat cultivars Baguette 18 and BIOINTA 3004. Different lower case letters above bars indicate a significant difference $(P<0.05)$.

a widely grown pasture grass occupying more than 90 million ha in Brazil, was proposed to provide a major source of wheat blast inoculum and to be the preferred host for pathogen recombination. Regarding blast disease of poaceaous crops and their wild relatives, a multilocus gene genealogy concordant with host preference indicates segregation of a new species, M. oryzae, from $M$. grisea (Couch \& Kohn, 2002). Moreover, recent advances in phylogenetic analyses of these fungi resulted in taxonomic revisions of Magnaporthales (Zhang et al., 2016). A comparative genomics analysis of host-specific isolates revealed gain and loss of genes as a major evolutionary mechanism driving host specialization in this pathogen species (Yoshida et al., 2016). The important role that weeds could play as secondary hosts of this disease in Argentina is confirmed by the results of the present study; isolates from weeds and grasses, collected in the province of Buenos Aires, were pathogenic on the wheat commercial cultivars tested under experimental conditions. Moreover, in 1987, M. oryzae was found infecting S. secundatum, a common grass in Argentina (Wolcan \& Perelló, 1987). In addition, annual ryegrass (L. multiflorum), another common host of M. oryzae, is one of the most widespread forage grasses in production systems of milk and meat from different regions of Argentina, due to its high potential to produce quality forage under different driving conditions. Further study on the role of an endemic Lolium-infecting pathogen $(\mathrm{MoL})$ and its relationship with MoT is recommended as it has been suggested that MoT and MoL may belong to a single 
Figure 6 Effect of infection by five different isolates of Magnaporthe spp. on the percentage germination of grain of wheat cultivars Baguette 18, BIOINTA 3004 and Klein Proteo. Different lower case letters above bars indicate a significant difference $(P<0.05)$.

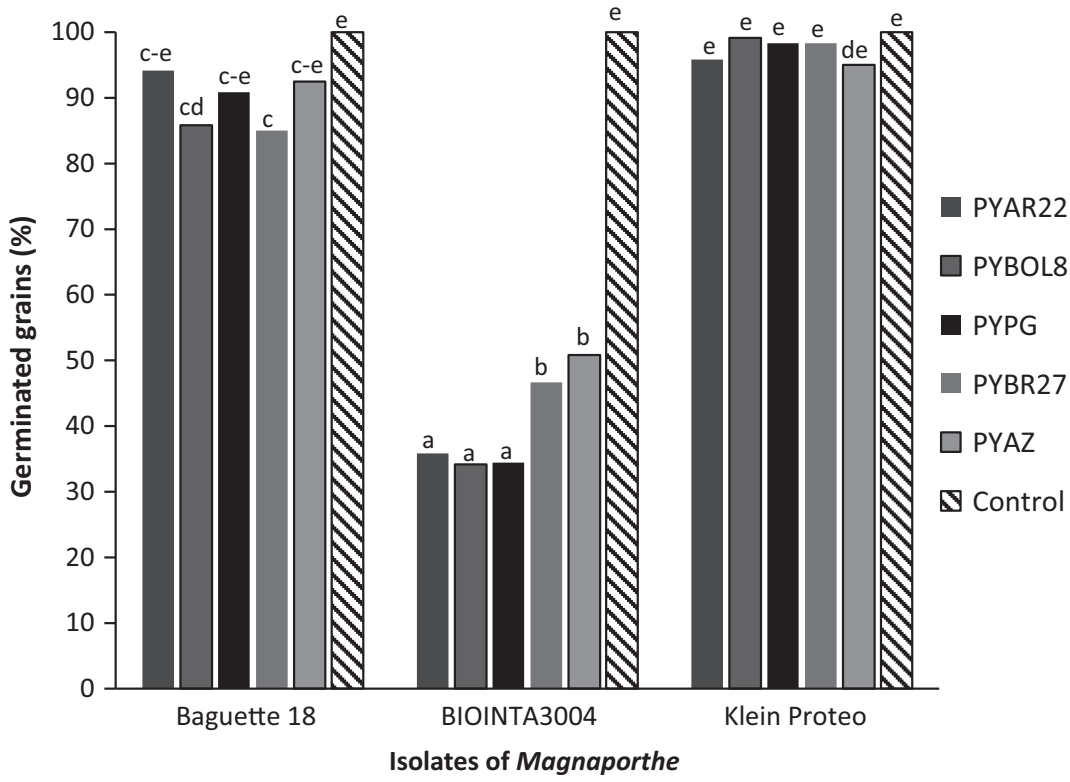

Table 5 Incidence (\%) of symptoms of discolouration (D) and softening (S) on wheat grains of cultivars Baguette 18, BIOINTA 3004 and Klein Proteo 14 days after the inoculation with five isolates of Magnaporthe spp.

\begin{tabular}{|c|c|c|c|c|c|c|}
\hline \multirow[b]{2}{*}{ Isolate } & \multicolumn{2}{|c|}{ Baguette 18} & \multicolumn{2}{|c|}{ BIOINTA 3004} & \multicolumn{2}{|c|}{ Klein Proteo } \\
\hline & $\mathrm{D}$ & S & D & S & $\mathrm{D}$ & S \\
\hline PY22 & 0.0 & 5.8 & 5.0 & 60.0 & 28.3 & 9.2 \\
\hline PYBOL & 10.0 & 4.2 & 0.0 & 60.8 & 34.2 & 0.0 \\
\hline PYPG & 8.3 & 8.3 & 1.7 & 64.2 & 25.0 & 0.0 \\
\hline PYBR & 6.7 & 5.8 & 1.7 & 50.8 & 20.0 & 0.0 \\
\hline PYAZ & 7.5 & 0.0 & 7.5 & 41.7 & 27.5 & 0.0 \\
\hline
\end{tabular}

pathogen super-population (Farman et al., 2016). As has been speculated in the USA (Mills et al., 2015), MoL may pose a threat to wheat production in Argentina if conditions are conducive for disease development and a susceptible cultivar is planted.

It has also been speculated that seedborne infection plays a vital role in the outbreak and dissemination of wheat blast. Little is known about the effect of M. oryzae on wheat seed germination, despite reports of the presence of the pathogen on seeds. Urashima et al. (2009) examined the effect of M. oryzae on wheat seeds in Brazil and observed a reduction in germination of $38 \%$ for cultivar CD104. In the present study, it was found that $M$. oryzae decreased germination by 1$65.9 \%$, indicating that the effect on germination depends on the variety of wheat and the isolate used. However, it is possible that results of studies on the transmission of disease from wheat seeds to seedlings may be associated with the methods used. Dias Martins et al. (2004) compared different methods for investigating disease transmission from triticale seeds infected with M. oryzae, such as seeding in filter paper and sterilized soil. They found that different methods yielded values ranging from $35 \%$ to $60 \%$ transmission. Thus, although there was variation between the methods used, they all demonstrated the importance of seeds as the primary source of this disease. The standard blotter method was used for the present investigation, with good effectiveness. Therefore, it could be safely concluded that the variability in germination percentage and in transmission of disease from seed to seedling between the three wheat cultivars assayed was a true result and depended on the isolate and wheat cultivar used.

In summary, this study has confirmed that isolates of M. oryzae have morphocultural variability according to the culture medium and conditions tested. In particular the colour of the colony, the rate of growth, and sporulation varied. The OMA medium and culture conditions of $12 \mathrm{~h} \mathrm{light} / 12 \mathrm{~h}$ dark were confirmed as the most favourable for $M$. oryzae growth and sporulation. Moreover, it is confirmed that the isolates of M. oryzae assayed are seedborne and pathogenic on the Argentinian commercial wheat cultivars tested. Variability in aggressiveness of isolates on the wheat cultivars tested depended on the isolate $\times$ cultivar interaction and the susceptibility of the germplasm currently under use in the Argentinian wheat agroecological area. Isolates collected from weeds in Argentina were also pathogenic for wheat, and could be a potential source of fungal inoculum, as well as playing an epidemiological role as green bridges in the absence of a wheat crop. Isolates collected from other countries of Latin America, such as Brazil, Paraguay and Bolivia, were also pathogenic on wheat at the heading stage, indicating a risk of infection from these spores and mycelium in material imported from these neighbouring countries into Argentina. It has been confirmed that MoT affects both the vegetative (seedlings) and reproductive (spikes) stages, thus affecting at 
least some of the performance parameters of the wheat crop (1000-grain weight). According to these results, a serious economic threat exists for Argentinian wheat, and therefore future studies of the entire pathosystem, in order to obtain vital information for the Argentinian wheat-producing areas, are recommended before the disease becomes widespread and established in wheat production areas.

\section{Acknowledgements}

The authors thank Professor Andreas Von Tiedemann, Department of Plant Pathology of the Georg August Universität, Göttingen, Germany, for providing the isolates of PYBOL and PYBR and Dr Fabiana Consolo from Instituto de Investigaciones en Biodiversidad y Biotecnología_Fundación para Investigaciones Biológicas Aplicadas (INBIOTEC_FIBA), Mar del Plata, Argentina, for providing the PYAZ isolate used in this study. This work was financed by CONICET and FCAyFUNLP projects.

\section{References}

Alberione E, Bainotti C, Cettour I, Salines J, 2008. Evaluación de enfermedades en trigos en siembra de verano en el NEA argentinoCampaña 2007/2008. In: Mirasson H, Faraldo ML, Baudino EM, eds. VII Congreso Nacional de Trigo. Santa Rosa, Argentina: Universidad Nacional de La Pampa, 1-10.

Aman A, 2016. 'Wheat blast' threatens yield - farmers in 6 districts complain of infection. [http://www.thedailystar.net/backpage/wheat-bla st-threatens-yield-784372]. Accessed 29 November 2016.

Bockus W, Cruz C, Stack J et al. 2013. Recovery plan for wheat blast caused by Magnaporthe oryzae Triticum pathotype. [https://www.ars. usda.gov/ARSUserFiles/opmp/Wheat \%20Blast \%20Recovery $\% 20 \mathrm{Plan} \%$ 20Final.pdf]. Accessed 2 December 2016.

Cabrera MG, Gutiérrez SA, 2007. Primer registro de Pyricularia oryzae en cultivos de trigo del NE de Argentina. In: Astiz Gasso M, Molina M, eds. Jornada de Actualización en Enfermedades de Trigo. Lavallol, Buenos Aires: Instituto Fitotécnico de Santa Catalina, 18-180.

Callaway E, 2016. Devastating wheat fungus appears in Asia for first time. Nature 532, 421-2.

Ceresini PC, Castroagudín VL, Maciel JL et al., 2016. The recent emergence and evolution of the wheat blast species complex in Brazil. In: Del Ponte EM, Bergstrom GC, Pavan W, Lazzaretti A, Cunha Fernandes JM, eds. Book of Abstracts, 5th International Symposium on Fusarium Head Blight and 2nd International Workshop on Wheat Blast, Florianopolis, SC, Brazil. Passo Fundo, Brazil: Universidade de Passo Fundo, 131.

Chavez A, Kholi M, 2015. Alternative hosts of Magnaporthe grisea of wheat in Paraguay. Investigación Agrararia 17, 1-5.

Consolo F, Martinez I, Sanabria A, Salerno G, Perelló A, 2016. Seed borne infection of wheat seeds by Pyricularia oryzae and its transmission to seedlings: preliminary studies in Argentina. In: Del Ponte EM, Bergstrom GC, Pavan W, Lazzaretti A, Cunha Fernandes JM, eds. Book of Abstracts, 5th International Symposium on Fusarium Head Blight and 2nd International Workshop on Wheat Blast, Florianopolis, SC, Brazil. Passo Fundo, Brazil: Universidad de Passo Fundo, 145.

Couch BC, Kohn LM, 2002. A multilocus gene genealogy concordant with host preference indicates segregation of a new species, Magnaporthe oryzae, from M. grisea. Mycologia 94, 683-93.

Cruz MFA, Maciel JL, Prestes AM, Scheeren PL, Silva MS, 2007. Resistência de genotipos de trigo à brusone e caracterização fenotípica de Pyricularia grisea. In: Reunido da Comisado Brasilera de Pesquisa de Trigo e Critícale. Seminario Técnico de Trigo 7. Londrina, Bazil: Embrapa Soja, Fundação Meridional, 191-6.

Cruz MFA, Prestes AM, Maciel JL, 2008. Reação de genótipos de trigo à brusone em diferentes estádios de desenvolvimeto. In: Proyecto Regional Trigo. Principales Logros y Avances. Passo Fundo, Brazil: Comissão Brasileira de Pesquisa de Trigo e Triticale, 33-5.

Cruz MFA, Prestes AM, Maciel JL, Scheeren PL, 2010. Resistência parcial à brusone de genótipos de trigo comum e sintético nos estádios de planta jovem e adulta. Tropical Plant Pathology 35, 24-31.

Cruz CD, Kiyuna J, Bockus WW, Todd TC, Stack JP, Valent B, 2015. Magnaporthe oryzae conidia on basal wheat leaves as a potential source of wheat blast inoculum. Plant Pathology 64, 1491-8.

Dias Martins T, Lavorenti NA, Urashima AS, 2004. Comparação entre métodos para avaliação de transmissão de Pyricularia grisea através de sementes em triticale. Fitopatologia Brasileira 29, 425-8.

Diekmann M, Putter CAJ, 1995. Small Grain Temperate Cereals. FAO/ IPGRI Technical Guidelines for the Safe Movement of Germplasm, no. 14. Rome, Italy: FAO/IPGRI.

Ellis MB, 1971. Dematiaceous Hyphomycetes. Kew, UK: Commonwealth Mycological Institute.

Ellis MB, 1976. More Dematiaceous Hyphomycetes. Kew, UK: Commonwealth Mycological Institute.

Farman M, Peterson G, Murdick L et al., 2016. Wheat blast and gray leaf spot: diseases caused by a single, genetically diverse pathogen super-population. In: Del Ponte EM, Bergstrom GC, Pavan W, Lazzaretti A, Cunha Fernandes JM, eds. Book of Abstracts, 5th International Symposium on Fusarium Head Blight and 2 nd International Workshop on Wheat Blast, Florianopolis, SC, Brazil. Passo Fundo, Brazil: Universidad de Passo Fundo, 132.

Gashaw G, Alemu T, Tesfaye K, 2014. Morphological, physiological and biochemical studies of Pyricularia grisea isolates causing blast disease on finger millet in Ethiopia. Journal of Applied Biosciences 74, 605971.

Gouchang S, Zongtan S, Shuyuan S, 1989. Preservation technique of Pyricularia oryzae conidia. Chinese Journal of Rice Science 3, 40-3.

Goulart ACP, Paiva F de A, 1990. Transmissão de Pyricularia oryzae através de sementes de trigo (Triticum aestivum). Fitopatología Brasileira 15, 359-62.

Goulart ACP, Paiva F de A, 2000. Incidência da brusone (Pyricularia oryzae) em diferentes cultivares de trigo (Triticum aestivum) em condições de campo. Fitopatologia Brasileira 7, 321-5.

Gutiérrez SA, Cúndom MA, 2015. Pyricularia oryzae en cultivos de cebada en Corrientes (Argentina). Summa Phytopathologica 4, 131820 .

Gutiérrez SA, Mazzanti de Castañón MA, Galmarini MR, 2000. Avances en el Conocimiento de Hospedantes Espontáneos de Pyricularia Oryzae en Argentina. UNNordeste: Comunicaciones Científicas y Tecnológicas.

Igarashi S, Utiamada CM, Kasuma AH, López RS, 1986. Pyricularia sp. em trigo. Ocurrencia de Pyricularia sp no Estado do Paraná. Fitopatología Brasilera 11, 351-2.

Islam MT, Croll D, Gladieux P et al., 2016. Emergence of wheat blast in Bangladesh was caused by a South American lineage of Magnaporthe oryzae. BMC Biology 14, 84.

Kohli MM, Metha YR, Guzmán E, Viedma L, Cubilla LE, 2011. Pyricularia blast - a threat to wheat cultivation. Czech Journal of Plant Breeding 47 (Special Issue), S130-4.

Malik SA, Khan MA, 1943. Parasitic fungi of the North-west Frontier province. Indian Journal of Agricultural Sciences 13, 522-7.

Martinez CA, 1971. Mancha gris de la moha (Setaria itálica [L.] Beauv.). Boletin de Divulgacion Técnica No. 7. Estacion Experimental Regional Agropecuaria, INTA, Buenos Aires, Hemisferio Sur 2, 106-13.

McRae W, 1922. Report of the Imperial mycologist. Pusa Agricultural Research Institute Scientific Report 1921-22, 44-50.

Meena BS, 2005. Morphological and Molecular Variability of Rice Blast Pathogen Pyricularia grisea. Dharwad, India: Dharwad University of 
Agricultural Sciences, Masters thesis.

Mills K, Paul P, Madden L, Peterson G, 2015. Preliminary assessment of differential susceptibility of soft red winter wheat cultivars to Lolium and Triticum pathotypes of Magnaporthe oryzae. [http://www.apsnet. org/meetings/Documents/2015_meeting_abstracts/aps2015abP162. htm]. Accessed 2 December 2016.

Perelló A, Martínez I, Molina M, 2015. First report of virulence and effects of Magnaporthe oryzae isolates causing wheat blast in Argentina. Plant Disease 99, 1177.

Perelló A, Martinez I, Sanabria A, Consolo F, 2016. Aggressiveness of Pyricularia oryzae isolates on seedlings and adult wheat plants of Argentinian varieties and their effect on 1000-grain weight. In: Del Ponte EM, Bergstrom GC, Pavan W, Lazzaretti A, Cunha Fernandes $\mathrm{JM}$, eds. Book of Abstracts, 5th International Symposium on Fusarium Head Blight and 2nd International Workshop on Wheat Blast, Florianopolis, SC, Brazil. Passo Fundo, Brazil: Universidad de Passo Fundo, 147.

Rayner RW, 1970. A Mycological Colour Chart. Kew, UK: CMI and British Mycological Society.

Rush M, Carver R, 1973. Ryegrass blast: a serious new disease in Louisiana. Louisiana Agriculture 16, 15.

Shaner G, Finney R, 1977. The effect of nitrogen fertilization on the expression of slow-mildewing in Knox wheat. Phytopathology 67, 1051-6.

Teixeira H, Machado JC, 2003. Transmissibilidade e efeito de Acremonium strictum em sementes de milho. Ciência e Agrotecnologia $25,1045-52$.

Tochinai Y, Nakano T, 1940. Studies on the nutritional physiology of Pyricularia oryzae. Journal of the Faculty of Agriculture 44, 183-229.

Trevathan LE, 1982. Pathogenicity on ryegrass and cultural variability of Mississippi isolates of Pyricularia oryzae. Plant Disease 66, 592-4.
Urashima AS, Igarashi S, Kato H, 1993. Host range, mating type, and fertility of Pyricularia grisea from wheat in Brazil. Plant Disease 77, 1211-6.

Urashima AS, Lavorent NA, Goulart CP, Mehta YR, 2004. Resistance spectra of wheat cultivars and virulence diversity of Magnaporthe grisea isolates in Brazil. Fitopatología Brasilera 29, 511-8.

Urashima A, Grosso C, Stabili A, 2009. Effect of Magnaporthe grisea on seed germination, yield and quality of wheat. In: Wang G, Valent B, eds. Advances in Genetic, Genomics and Control of Rice Blast Disease. New York, NY, USA: Springer Science and Business Media, 267-77.

Vales MJ, Huallpa B, Anzoátegui T, Mostacedo B, Cazon MI, 2016. Efficient breeding strategy for wheat blast disease resistance in Bolivia - use of the experience acquired on rice blast. In: Del Ponte EM, Bergstrom GC, Pavan W, Lazzaretti A, Cunha Fernandes JM, eds. Book of Abstracts, 5th International Symposium on Fusarium Head Blight and 2nd International Workshop on Wheat Blast, Florianopolis, SC, Brazil. Passo Fundo, Brazil: Universidad de Passo Fundo, 130.

Wolcan S, Perelló A, 1987. Magnaporthe grisea (Hebert) Yaegashi \& Udagawa anamorfo: Pyricularia oryzae [Cke.] Sacc.) sobre Stenotaphrum secundatum (Walt.) Kuntze en la Argentina. Revista de Agronomia del NO Argentino 24, 171.

Yoshida K, Saunders DGO, Mitsuoka C et al., 2016. Host specialization of the blast fungus Magnaporthe oryzae is associated with dynamic gain and loss of genes linked to transposable elements. BMC Genomics 17, 370 .

Zadoks JC, 1972. Methodology of epidemiological research. Annual Review of Phytopathology 10, 253-76.

Zhang N, Luo J, Rossman A et al., 2016. Generic names in Magnaporthales. IMA Fungus 7, 155-9. 